\title{
Influence of Quality of Work Life towards Psychological Well-Being and Turnover Intention of Nurses and Midwives in Hospital
}

\section{Pengaruh Kualitas Kehidupan Kerja terhadap Psychological Well-Being dan Keinginan Pindah Kerja Perawat dan Bidan di Rumah Sakit}

Indra Wahju Hardjanti*, Noermijati**, Aryo Dewanto*

*Master of Hospital Management Study Program, Faculty of Medicine, Brawijaya University, Malang, Indonesia, **Faculty of Economics and Business, Brawijaya University, Malang, Indonesia

\begin{abstract}
Nurses have been trained to provide patient care and improve patients' quality of life, but their own quality of work life and psychological well-being are often disregarded. Nurses' low quality of work life in hospital leads to nurses' high turnover. The high rate of nurses' and midwives' turnover in hospital X Malang is an issue that requires hospital management attention to prevent low quality of health services in the hospital. The purpose of this study was to determine relation between quality of work life, psychological well-being and turnover intention of nurses and midwives in the hospital. This study used quantitative correlation design with cross-sectional approach, and the data were analyzed using Partial Least Square. The results showed that the quality of work life positively and significantly affected the psychological well-being of nurses, quality of work life significantly and negatively affected turnover intention, while psychological well-being did not affect the turnover intention, so the psychological well-being did not mediate the effect of quality of work life on turnover intention. Quality of work life influences both psychological well-being and turnover intention, so the improvement quality of work life will reduce turnover intention and inhance the psychological well-being.
\end{abstract}

Keywords: Psychological well-being, quality of work life, turnover intention

\begin{abstract}
Abstrak ing.

Kata kunci: Psychological well-being, kualitas kehidupan kerja, keinginan pindah kerja

How to Cite: Hardjanti IW, Noermijati, Dewanto A. Influence of quality of work life towards psychological well-being and turnover intention of nurses and midwives in hospital . Kesmas: National Public Health Journal. 2017; 12 (1): 7-14. (doi: 10.21109/kesmas.v12i1.1144)
\end{abstract}

Selama ini perawat telah dilatih untuk memberikan perawatan pasien dan meningkatkan kualitas hidup pasien, namun kualitas kehidupan kerja dan psychological well-being mereka sendiri terabaikan. Rendahnya kualitas kehidupan kerja perawat di rumah sakit menyebabkan tingginya keinginan pindah kerja perawat. Tingginya angka keinginan pindah kerja perawat dan bidan di Rumah Sakit X Malang merupakan masalah yang memerlukan perhatian dari manajemen rumah sakit agar tidak menjadi menyebabkan rendahnya mutu pelayanan kesehatan di rumah sakit. Penelitian ini bertujuan untuk mengetahui hubungan antara kualitas kehidupan kerja, psychological well-being, dan keinginan pindah kerja perawat dan bidan di rumah sakit. Penelitian ini menggunakan desain penelitian kuantitatif korelasional dengan pendekatan potong lintang. Analisis data menggunakan Partial Least Square. Hasil penelitian menunjukkan kualitas kehidupan kerja berpengaruh positif dan signifikan terhadap psychological well-being perawat, kualitas kehidupan kerja berpengaruh negatif dan signifikan terhadap keinginan pindah kerja, psychological well-being tidak berpengaruh terhadap keinginan pindah kerja, sehingga psychological well-being tidak memediasi pengaruh kualitas kehidupan kerja terhadap keinginan pindah kerja. Kualitas kehidupan kerja berpengaruh pada psychological well-being dan keinginan pindah kerja, sehingga peningkatan kualitas kehidupan kerja akan mengurangi keinginan pindah kerja dan meningkatkan psychological well-be-

Correspondence: Indra Wahju Hardjanti, Master of Hospital Management Study Program Faculty of Medicine Brawijaya University, Malang, Indonesia, Phone: +62341 568989, e-mail: iwhardjanti@gmail.com

Received: November $14^{\text {th }} 2016$

Revised: May 09th 2017

Accepted: May 22nd 2017 


\section{Introduction}

Development in health services requires hospitals to adapt to any changes that occur. Hospitals must be able to innovate to continue their life in developing the organization. The success of developing the organization is influenced by human resource quality and employees' support to achieve the organizational goals. ${ }^{1,2}$ Human resource management has an important role to improve employees' quality and productivity. Therefore, a good and conducive working environment needs to be settled, so employees will feel comfortable in performing their duties. $^{3}$

Hospitals are always required to improve health service quality, so poor service quality to patients will be spotted. One of the main services in health care for patients in hospital is nursing care using nurses as the human resources to carry out the task. This puts nurses on a crucial role that completely affects hospital service quality. ${ }^{4}$ The important role of nurses has not matched the provision of a conducive working environment for them. ${ }^{4}$ Moradi et al., ${ }^{4}$ stated that nurses have been trained to provide patient care and improve patients' quality of life, but their need, quality of working life, and psychological well-being are neglected. Further stated that low quality of nurses working life in hospitals causes high absenteeism and nurses' turnover.

Turnover intention has become a phenomenon that should be noticed.$^{5}$ Turnover intention is a predictor for the occurrence of turnover behavior, even the turnover itself is a behavior pattern manifestation of psychological reactions. ${ }^{6}$ Turnover has negative impacts that harm the hospital, such as the training cost that has been invested in employees, the performance level of sacrificed employee, and high cost for employee re-recruiting and retraining, so turnover affects the organization's ability to improve service quality. ${ }^{7}$

Several studies link turnover intention to quality of work life and psychological well-being as done at previous study. 3,5,7-15 Hospital management needs to retain qualified health care professionals to provide an environment with good quality of work life. ${ }^{7}$ The existence of a good quality of work life will raise employees desire to stay and remain in the organization. ${ }^{7,9}$ In addition, high psychological well-being will also reduce employee turnover. ${ }^{5,14,15}$

X Hospital Malang had employed 202 people consisting of 88 nurses and midwives by the end of 2015. X Hospital Malang had as high as 39\% turnover of nurses and midwives in 2015. The rate is considered very high because according to Gillis in Mardiana et al., 16 nurses discharge from a hospital normally ranging between $5-10 \%$ per year. The interview to some nurses at X Hospital Malang on preliminary studies conducted in January 2016 showed that there were employees' dis- satisfaction over income, high workload, large number of patients, and no rules on career development. It describes some neglected aspects of quality of work life and psychological well-being of nurses at X Hospital Malang. In fact, neglected quality of work life and psychological well-being are likely as ones of the causes of high turnover intention in hospital.

This study aimed to determine the influence of the quality of work life on turnover intention of nurses and midwives at X Hospital Malang. The results of this study are expectedly used as a consideration in the preparation of hospital management strategies to understand and address the issue of quality of work life and psychological well-being of nurses and midwives at Hospital X Malang.

\section{Method}

This study used quantitative correlation design with cross-sectional approach. The study was conducted at X Hospital Malang in March 2016, and data collection was done by distributing questionnaires to all nurses and midwives at X Hospital Malang that have worked for more than four months. The sampling method was total sampling. Respondents collected in this study were 72 people. Variables used in this study were quality of work life (with six indicators that were management leadership-values, work pressures, autonomy-fulfilment, salary, pride in organization, and happiness and progress), ${ }^{17}$ psychological well-being (with six indicators that were self-acceptance, positive relations with others, autonomy, environmental mastery, purpose in life, and personal growth), 18 and turnover intention (with one indicator that was turnover intention). ${ }^{11,19}$ Measurement category of respondent's distribution using criteria low (1.002.33), medium (2.34-3.67), and high (3.68-5.00). ${ }^{20}$ The conceptual framework is shown at Figure 1. The study instrument was questionnaire that had been modified from previous study. This instrument had been tested for the validity and reliability, and the result of this test showed that was valid and reliable to this study. This study used Partial Least Square (PLS) analysis.

\section{Results}

Quality of work life variable had an average of 3.76 included in high category. However, there was one indicator of quality of work life, namely salaries categorized as moderate criteria (3.23). Psychological well-being variable had an average of 4.07 considered as high criterion. Turnover intention variable had an average of 3.62, included as medium criterion. Although the variables in this study were at moderate to high criteria, there were still objects that needed the attention of hospital management, namely quality of work life and turnover intention variables. 


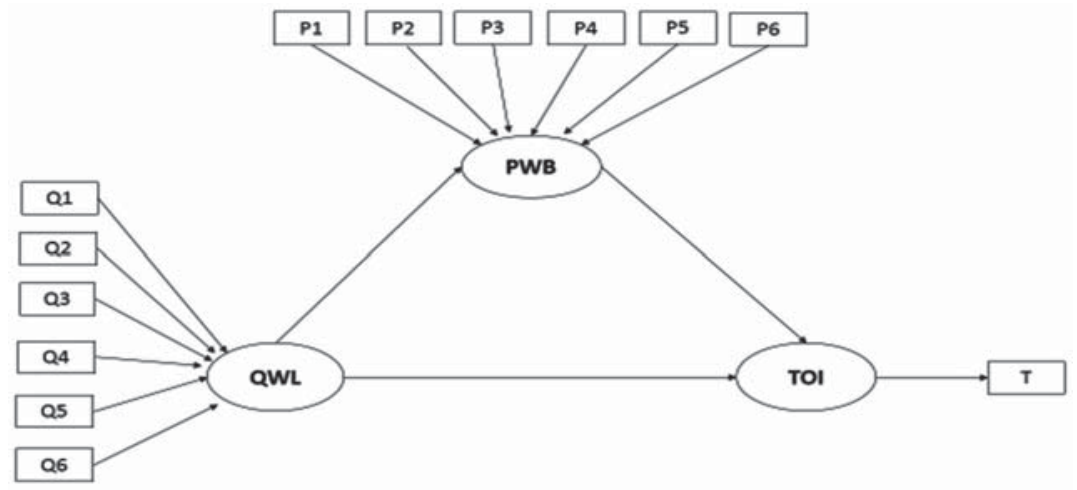

Figure 1. Conceptual Framework

\begin{tabular}{|c|c|c|c|}
\hline Variable & Indicator & Mean Value of Indicator & Mean Value of Variable \\
\hline \multirow[t]{6}{*}{ Quality of work life } & Management-leadership-values & 3.72 & 3.76 \\
\hline & Work pressures & 3.71 & \\
\hline & Autonomy-fulfilment & 3.96 & \\
\hline & Salary & 3.23 & \\
\hline & Pride in organization & 3.95 & \\
\hline & Happiness and progress & 3.97 & \\
\hline \multirow[t]{6}{*}{ Psychological well-being } & Self-acceptance & 4.04 & 4.07 \\
\hline & Positive relations with others & 4.09 & \\
\hline & Autonomy & 3.97 & \\
\hline & Environmental mastery & 3.83 & \\
\hline & Purpose in life & 4.16 & \\
\hline & Personal growth & 4.31 & \\
\hline Turnover intention & Turnover intention & 3.62 & 3.62 \\
\hline
\end{tabular}

Quality of work life variable revealed several circumstances that needed attention, i.e. in the aspect of salary adequacy, there were $38.9 \%$ of respondents who were hesitant to strongly disagree that the salary was indicated enough; in the aspect of flexibility of working hours, there were $52.8 \%$ of respondents who were hesitant to strongly disagree that the working hour was flexible; in the indicator of management and leadership, there was one aspect that had the lowest average score (2.72), i.e. support from managers when error occurs; and in the working pressure indicator, there was one aspect that had the lowest average score (3.32), i.e. the work cannot be completed within working hours and $38.9 \%$ of respondents felt that they could not finish the job during working hours. Of turnover intention variables, several aspects which needed attention were that there was still a consideration to resign $(44.5 \%)$ and respondents who sought information about job vacancy elsewhere $(41.6 \%)$. The results of data analysis using PLS showed the path diagram of this study as presented in Figure 2.

Figure 2 presents that in measurement model of quality of work life variable, an indicator of pride in organization was obtained. Public perception in the workplace (pride in the organization that is general perception of workplace) (Q5) had the greatest loading value (0.777). This means an indicator of pride in organization that is public perception in the workplace (Q5) was the most dominant indicator in measuring quality of work life variable. Psychological well-being variable measurement model showed that environmental mastery indicator (P4) had the greatest loading value. This means that environmental mastery indicators (P4) was the most dominant indicator in measuring psychological well-being variable.

$\mathrm{R}$-square result of psychological well-being variable was 0.531 . It shows that the contribution of quality of life to psychological well-being variable was $53.1 \%$, while the remaining $46.9 \%$ was contributed by other variables that are not addressed in this study. Furthermore, $\mathrm{R}$-square of turnover intention variable was 0.246 . This shows that the contribution of the quality of work life and psychological well-being variables to turnover intention variable was $24.6 \%$, while the remaining $75.4 \%$ was contributed by other variables that were not covered in this study. Q-square shows that contribution of quality of work life and psychological well-being variables to turnover intention variable was $64.6 \%$. It means that turnover intention variable in this study could be explained by quality of work life and psychological well-be- 


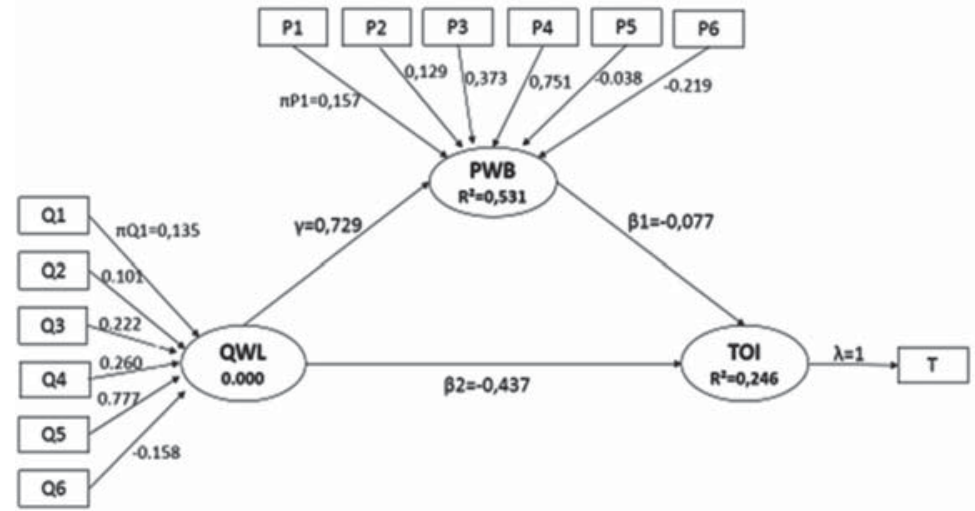

Figure 2. Line Diagram

Table 2. Results of Significance Tests

\begin{tabular}{llccrl}
\hline Exogenous & Endogenous & $\begin{array}{c}\text { Original Sample } \\
\text { (O) }\end{array}$ & $\begin{array}{c}\text { Standard Error } \\
\text { (STERR) }\end{array}$ & $\begin{array}{c}\text { t Statistics } \\
\text { (|O/STERR) }\end{array}$ & Note \\
\hline Quality of work life & Psychological well-being & 0.729 & 0.028 & 26.139 & Significant \\
Quality of work life & Turnover intention & 0.437 & 0.060 & 7.324 & Significant \\
Psychological well-being & Turnover intention & 0.077 & 0.057 & 1.357 & Insignificant \\
\hline
\end{tabular}

ing variables of $64.6 \%$, while $35.4 \%$ was explained by other variables outside this study.

The results in Table 2 showed that the value of $t$ statistic relation between quality of work life on the psychological well-being of nurses was at 26.139, ( $t$ value $>$ 1.96). This means there was a significant influence of quality of work life on nurses' psychological well-being. T statistical relation value between quality of work life on the turnover intention of nurses' was at 7.324 ( $\mathrm{t}$ value $>$ 1.96). This indicates a significant influence of quality of work life on nurses' turnover intention. T statistical relation value between psychological well-being on nurses' turnover intention was 1.357 ( $\mathrm{t}$ value $<1.96)$. This means there was no significant influence of psychological well-being on the turnover intention of nurses.

Indirect test of psychological well-being mediated the effect of quality of work life on nurses' turnover intention showed that the influence of quality of work life on nurses' turnover intention through nurses' psychological wellbeing obtained $t$ statistic value $<1.96$ or as many as 1.355. This shows that there was no significant effect of the quality of work life on nurses' turnover intention through nurses' psychological well-being. Therefore, nurses' psychological well-being cannot mediate the effect of quality of work life on nurses' turnover intention.

Table 2 also informs that quality of work life variable has the greatest total effect on nurses' and midwives' turnover intention with a total effect of 0494. Thus, quality of work life has the most dominant influence on nurses' and midwives' turnover intention.

\section{Discussion \\ Quality of Work Life, Psychological Well-Being, and Turnover Intention}

Respondents' quality of work life in high criterion should not make the hospital ignore that there were still some considerations to make. Management support to employees and fair treatment were positively correlated with the quality of work life. ${ }^{7,21}$ The hospital needs to pay attention to managerial support and treatment as a quality of work life aspect to obtain better quality of care for patients. In working pressure aspect, there were employees who felt overwhelmed with their jobs, such as jobs that cannot be completed during working hours. Workload alone would lead to job stress, and stress-related problems result in low job satisfaction, poor quality of performance, increased absenteeism, and high turnover. ${ }^{22}$

From the average criteria of pay and benefit indicator, the hospital need to pay attention on salary adequacy and flexibility of working hours. Robbins and Judge, 23 states that today the workers prefer a job that gives them flexible schedule. As a result, any organizations will be difficult to retain most proficient and motivated workers when those are not met. In medical domain, especially those who offers nursing services will be difficult to realize the flexibility in arranging work schedules, however, it can be overcome by sufficient nursing personnel. In fact, at X Hospital Malang, limited nursing staff can hamper such flexibility realization. Hospital management should concern pride in organization indicator because this indicator has the biggest contribution to nurses' and midwives' quality of work life, so any small changes in 
these indicators will impact the quality of work life.

Nurses' and midwives' psychological well-being in X Hospital Malang was in high criteria. Even though con sidered as high criteria, the mean value of environmental mastery indicator obtained the lowest compared to other psychological well-being indicators. Hospital management must concern this situation because this indicator has the largest contribution to the psychological wellbeing of nurses and midwives, since any slight changes in these indicators will have an impact on the psychological well-being. People who can master the environment will be able to create an environment that matches their physical condition. This ability is influenced by maturity, especially the ability to manipulate and control complex environments through mental and physical activity. ${ }^{24}$

Turnover intention of nurses and midwives in $\mathrm{X}$ Hospital Malang was in moderate criteria. The hospital could not ignore that the intention to resign was still pretty much in the mind of nurses and midwives. Management of human resources at X Hospital Malang must give attention to formulate strategies to suppress real turnover among nurses and midwives at the hospital. Streers and Mowday, ${ }^{16}$ states that a person who wants to leave his job (due to lack of opportunities, constraints of family, etc.) can perform various other forms of quitting, such as absentee, indolent in the work, sabotage, and provide a lower quality of work. Basically, there is no hospital that can prevent employee turnover, but if there is a high turnover rate and not immediately suppressed, it could disrupt service to patients and is a problem for the whole hospital.

\section{Effect of Quality of Work Life on Psychological Well-Being}

Hypothesis testing results indicated that the quality of work life impacts positively and significantly on nurses' psychological well-being. This is consistent with previous studies conducted by Rathi, ${ }^{8}$ in India, Ilgan et al., ${ }^{25}$ on teacher at school in Turkey, and Zulkarnain, ${ }^{3}$ on a public service organization in Medan that there is a positive and significant relation between individual quality of work life and psychological well-being. In addition, quality of work life is found to be an important predictor of employees' psychological well-being. The study findings by Rathi, ${ }^{8}$ give an insight into various aspects of work and work environment that contribute significantly to employees' well-being. This study suggested that HR must consider their employees' quality of work life when formulating the organization's policies.

According to Zulkarnain, ${ }^{3}$ employees with good quality of work life will likely to be satisfied with their psychological well-being. This is because the quality of work life is associated with improvements made within the organization which leads to increased organizational effectiveness, and staff-focused quality of work life de- velopment will increase workers' psychological well-being which in turn improves the organizational performance.

Pride in organization indicator is the most contributing indicator to shaping nurses' quality of work life, and indicator of environmental mastery has the biggest contribution to nurses' psychological well-being at $\mathrm{X}$ Hospital. Nurses and midwives at X Hospital, who predominantly are young and fresh graduate and regard the job as a challenge of gaining experience, make them proud of the hospital they work for. This is indicated by excitement of going to work, proud of their work place, and feel their work environment is pleasant. The pride in organization as an indicator of quality of work life can improve these indicators in psychological well-being, such as environmental mastery. Increasing quality of work life can provide nurses' and midwives' psychological well-being, for example making nurses and midwives not to feel pressured by the demands of everyday life, making them comfortable with the people around, and enabling them to set the daily tasks well.

\section{Effect of Quality of Work Life on Turnover Intention}

Hypothesis testing results indicate that quality of work life affected negatively and significantly on nurses' turnover intention. This supports previous study which states that quality of work life plays an important role in nurses' turnover, and stated that quality of work life related negatively and significantly to turnover intention, as shown in study by Mosadeghrad, ${ }^{7}$ Mosadeghrad et al., ${ }^{9}$ Lee et al., ${ }^{10}$ Surienty et al., ${ }^{11}$ and Chen et al., ${ }^{12}$ which states that quality of work life affects negatively to turnover intention, so organizations must find ways to improve employee quality of work life. Likewise, Lee et al., 10 who examined nurses quality of work life in Taiwan stated that low quality of work life will cause high turnover intention, and can continue into a significant turnover. That is because jobs are open widely for nurses in Taiwan, so they easily find a new job. Huang et $a l .{ }^{26}$ in a study of auditors who work at public accounting firms in Taiwan also found that aspects of quality of work life were significant predictors of commitment and turnover intention .

Study by Mosadeghrad, ${ }^{7}$ shows that employees' quality of work life related to quality of management and organizational leadership. Management support to employees and fair treatment by management positively correlated with quality of work life. Lack of control, autonomy, and participation in decision-making are related to employee quality of work life that later lead to employee turnover. Salaries also correlated with employees' quality of work life and turnover intention. Employees can leave their organization to a higher salary. In addition, the fairness of the compensation system of an organization is 
important for employees. Employees who face a fair compensation system will have a low turnover intention In addition, work stress negatively related to employee quality of work life. Employees who are most dissatisfied with salary, promotion, job security, participation in decision-making are likely to experience higher job stress level. Job stress can have a detrimental effect on the individual's physical as well as mental and emotional health. High level of work stress has been associated with staffs' high absenteeism and low productivity. Work stress also negatively related to quality of service.

Nurses' and midwives' quality of work life in X Hospital was measured as high criterion, while nurses' and midwives' turnover intention was in moderate criteria. Quality of work life will decrease the intention to resign. At X Hospital, nurses and midwives assumed that hospital leadership and management, work pressure faced, autonomy, salary and work load, pride in organization, and their happiness and progress were acceptable. The nurses and midwives who were still young, fresh graduate, and inexperienced appointed their work at X Hospital as a place for gaining experience, so that they could still accept some lacking aspects, such as supervisor support, salary, and work pressure. It leads them to resist the urge to find another job. In addition, the closeness of house to the workplace and the lack of employment choice of as non-accredited college graduates make them prefer to discourage themselves to leave the job. Nurses' and midwives' quality of work life enhanced by improving the supervisor support, salary, and work pressure is expected to improve productivity, quality of service, and reduce turnover intention.

\section{Effect of Psychological Well-Being on Turnover Intention}

Hypothesis testing results showed that the psychological well-being of nurses did not significantly influence nurses' turnover intention. This is in contrast with study which claimed that psychological well-being significantly affected on turnover intention as in the results of study by Amin and Akbar, ${ }^{5}$ Wright and Bonett, ${ }^{13}$ Brunetto et al., 14 and Siu et al., ${ }^{15}$. Wright and Bonett, 13 found that psychological well-being is a predictor of turnover intention on managerial employees in a big company in West Coast, USA.

So far, previous study on the relation of psychological well-being and turnover intention were carried on outside health organizations, such as hotel employees and managerial employees of a company. ${ }^{5,13}$ Medical study in this area is very limited. In addition, study about psychological well-being on turnover intention often involves other variables, such as psychological capital, employee engagement, job satisfaction, job separation, and organizational commitment.

Young and fresh graduate nurses and midwives illus- trated that their work experience was still low, so they were looking for a job as a way to gain experience and avoid unemployment status. Besides, single nurses and midwives dominated the respondents, so it can be concluded that their life demand remained low. These are the causes of influence of psychological well-being on turnover intention to become insignificant, because nurses and midwives were more likely to seek for work experience, avoid unemployment status, and had low demand of life, so the desire to quit from work is low. Closeness factor from home to the workplace and lack of job options in other hospitals because of their non-accredited college graduates were also factors that made nurses and midwives to choose to remain at X Hospital. According Surienty et al., ${ }^{11}$ young respondents at early career stage might assume the challenge of work as a motivator and accept the job as an interesting piece, so it does not cause any desire to leave the work.

\section{Psychological Well-Being as Mediating the Effect of Quality of Work Life on Turnover Intention}

Relation between quality of work life and nurses' turnover intention through the psychological well-being showed a negative and in significant influence. Therefore, nurses' psychological well-being cannot mediate the effect of quality of work life on nurses' turnover intention. Previous study suggested that quality of work life affected on psychological well-being, as Rathi, ${ }^{8}$ and Zulkarnain, ${ }^{3}$ did; quality of work life influenced turnover intention based on study by Mosadeghrad, ${ }^{7}$ Mosadeghrad et al., ${ }^{9}$ Lee et al., ${ }^{10}$ Surienty et al., ${ }^{11}$ and Chen et al.,12; and psychological well-being affected the turnover intention as in study by Amin and Akbar, 5 Bonett Wright, ${ }^{13}$ Brunetto et al., ${ }^{14}$ and Siu et al., ${ }^{15}$. However, this study found that psychological well-being did not significantly affect turnover intention, so it could be said that psychological well-being did not mediate the effect of quality of work life on turnover intention. Furthermore, the data analysis also showed that the variables that had the greatest effect on the total turnover intention of nurses was the quality of work life. Thus the quality of work life had the most dominant influence on nurses' turnover intention. This outcome can be used as reference for X Hospital Malang to further optimize nurses' and midwives' quality of work life. Q-square results were quite high and represented contribution of quality of work life and psychological well-being on turnover intention. It can be a reference to pay more attention to nurses' and midwives' quality of work life at X Hospital. Likewise, R-square psychological well-being that demonstrates the contribution of quality of work life can also be used as input that improving the quality of work life will have an impact on reducing turnover intention and on improving the psychological well-being. 


\section{Implications of Study Results}

The results of this study can be used as a reference for X Hospital Malang to further enhance nurses' and midwives' quality of work life since improving the quality of work life will impact on decreasing turnover intention and on improving the psychological well-being. However, the success of quality of work life program depends on a partnership between management and employees. Therefore, the human resources department at X Hospital Malang should be stimulated to monitor the quality of work life of nurses and midwives and to improve it by implementing human resources policies.

Improving the quality of work life in this hospital can be done by creating a clear standard operating procedure (SOP) about job description, reward and punishment, and calculation of the workload, and then followed with SOP socialization before it is implemented. SOP is created to improve manager support and fair treatment to employees, appropriate workload with capabilities and resources of employees, providing fair compensation and improved nurses' and midwives' work-life balance. Pride in organization that is a key factor in quality of work life preparation needs further attention. It can be done by improving conducive work environment to create more employees' engagement, so that employees are more eager to go to work, have pride in hospital work, and feel fun on the work environment.

Further study can be extended by adding other variables that are not covered in this study, such as employee engagement or organizational commitment. Besides, qualitative study method on quality of work life, psychological well-being and turnover intention is recommended for future studies because it further discloses the conditions of quality of work life, psychological well-being, and turnover intention in the hospital.

\section{Conclusion}

First, the quality of work life impacts positively and significantly on nurses' psychological well-being. The results also show that the quality of work life affects negatively and significantly on nurses' turnover intention. Psychological well-being of nurses still has influence on turnover intention, although it is small, but the influence is not significant. This means that nurses' psychological well-being otherwise cannot mediate the effect of quality of work life on nurses' turnover intention. Second, indicator of pride in organization is the most dominant indicator in measuring quality of work life variable, while mastery of environment indicator is the most dominant indicator in measuring psychological well-being variable. Third, quality of work life has the most dominant influence on nurses' turnover intention. Contributions of quality of work life influence and psychological well-being variable to turnover intention variable as a whole, both directly and indirectly, may become a reference to focus on nurses' and midwives' quality of work life at X Hospital, thus improving the quality of work life will reduce turnover intention and improve the psychological well-being.

\section{Acknowledgment}

Our sincere gratitude to the director of X Hospital Malang for the permission to conduct this study there, as well as all nurses and midwives at X Hospital Malang who have participated at data collection for this study.

\section{References}

1. Khetavath PS. An empirical analysis of quality of work life of employees in Indian private sector organizations. International Conference on Trends in Economics, Humanities and Management; March 27-28, 2015; Singapore 2015; 32-6.

2. Sirin M, Sokmen SM. Quality of nursing work life scale: the psychometric evaluation of the Turkish Version. International Journal. 2015; 8(3); 543-54.

3. Zulkarnain A. The mediating effect of quality of work life on the relationship between career development and psychological well-being. International Journal of Research Studies in Psychology. 2013; 2(3); 67 80.

4. Moradi T, Maghaminejad F, Azizi-Fini I. Quality of working life of nurses and its related factors. Nursing and Midwifery Studies. 2014; 3(2): e1940.

5. Amin Z, Akbar KP. Analysis of psychological well-being and turnover intentions of hotel employees: An empirical study. International Journal of Innovation and Applied Studies. 2013; 3(3): 662-71.

6. Martin A, Roodt G. Perceptions of organisational commitment, job satisfaction and turnover intentions in a post-merger South African tertiary institution. South African Journal of Industrial Psychology. 2008; 34(1): 23-31.

7. Mosadeghrad AM. Quality of working life: an antecedent to employee turnover intention. International journal of health policy and management. 2013; 1(1): 43-50.

8. Rathi N. Relationship of quality of work life with employees' psychological well-being. International journal of business insights \& transformation. 2009; 3(1): 53-60.

9. Mosadeghrad AM, Ferlie E, Rosenberg D. A study of the relationship between job satisfaction, organizational commitment and turnover intention among hospital employees. Health Services Management Research. 2008; 21(4): 211-27.

10. Lee YW, Dai YT, Park CG, McCreary LL. Predicting quality of work life on nurses' intention to leave. Journal of Nursing Scholarship. 2013; 45(2): 160-8.

11. Surienty L, Ramayah T, Lo M-C, Tarmizi AN. Quality of work life and turnover intention: a partial least square (PLS) approach. Social Indicators Study. 2014; 119(1): 405-20.

12. Chen RJ, Yu CW, Chao CM, Cheng BW. Relationships among work value, quality of work life, and turnover intension in nurses in Yunlin, Taiwan. International Journal of Organizational Innovation. 2014; 6(4): 99. 
13. Wright TA, Bonett DG. Job satisfaction and psychological well-being as nonadditive predictors of workplace turnover. Journal of Management. 2007; 33(2): 141-60.

14. Brunetto Y, Teo ST, Shacklock K, Farr-Wharton R. Emotional intelligence, job satisfaction, well?being and engagement: explaining organisational commitment and turnover intentions in policing. Human Resource Management Journal. 2012; 22(4): 428-41.

15. Siu OL, Cheung F, Lui S. Linking positive emotions to work well-being and turnover intention among Hong Kong police officers: The role of psychological capital. Journal of Happiness Studies. 2014; 16(2): 36780.

16. Mardiana I, Hubeis AVS, Panjaitan NK. Hubungan kepuasan kerja dengan turnover intentions pada perawat Rumah Sakit Dhuafa. Manajemen IKM: Jurnal Manajemen Pengembangan Industri Kecil Menengah. 2014; 9(2): 119-30.

17. Denvir A, Hillage J, Cox A, Sinclair A, Pearmain D. Quality of working life in the UK: Institute for Employment Studies; 2008.

18. Ryff CD. Happiness is everything, or is it? Explorations on the meaning of psychological well-being. Journal of personality and social psychology [online]. 1989 [cited 2016 Jun 5]; 57(6): 1069. Available from: http://aging.wisc.edu/pdfs/379.pdf.

19. Yin-Fah BC, Foon YS, Chee-Leong L, Osman S. An exploratory study on turnover intention among private sector employees. International Journal of Business and Management. 2010; 5(8): 57.

20. Sugiyono. Statistik untuk penelitian. Bandung: Alfabeta; 2014.

21. Allameh SM, Ghazinour S, Aghaei M, Khodaei SA. Analyzing the effect of servant leadership on quality of work life in Isfahan Gas Company (With emphasis on the teaching of Nahjolbalaghe). International Journal of Management Academy. 2015; 3(2): 28-38.

22. Chitra D, Mahalakshmi V. A study on employees' perception on quality of work life and job Satisfaction in manufacturing organization, an Empirical study. International Journal of Trade and Commerce. 2012; 1(2): $175-84$

23. Robbins SP, Judge TA. Perilaku Organisasi Edisi 16. 16 ed. Jakarta: Penerbit Salemba Empat; 2015.

24. Haryanto R, Suyasa P. Persepsi terhadap job characteristic model, psychological well-being, dan performance (studi pada karyawan PT. X). Phronesis. 2007; 9(1): 67-92.

25. Ilgan A, Özü-Cengiz Ö, Ata A, Akram M. The relationship between teachers' psychological well-being and their quality of school work life. The Journal of Happiness \& Well-Being. 2015; 3 (2): 159-81.

26. Huang T-C, Lawler J, Lei C-Y. The effects of quality of work life on commitment and turnover intention. Social Behavior and Personality: an International Journal. 2007; 35(6): 735-50. 